\title{
Sistem Informasi Pengajuan Cuti dan Izin Berbasis Web
}

\author{
Fatoni $^{[1]^{*}}$, Dony Wahyu Isprananda ${ }^{[2]}$, Ahmad Syazili ${ }^{[3]}$ \\ Program Studi Teknik Informatika, \\ Universitas Bina Darma ${ }^{[1],[2],[3]}$ \\ Jl. Ahmad Yani No. 3 Seberang Ulu 1 Plaju Palembang, 30264 \\ fatoni@binadarma.ac.id ${ }^{[1]}$,dna.extrim@gmail.com ${ }^{[2]}$, syazili@binadarma.ac.id ${ }^{[3]}$
}

\begin{abstract}
Bina Darma University is an educational institution that has the obligation to provide leave rights for its employees and lecturers. For the process of implementing, managing, calculating, replacing leave will be the task of the Directorate of Human Resources (DSDM). DSDM has provisions regarding rules for granting leave or permission not to work. Employees and lecturers who will apply for leave must submit the application in writing using the leave application form. The application of this manual method has several weaknesses, namely lack of efficiency, takes a long time because it has not been computerized. Also less effective in the work process, because of the many uses of paper so difficult to control the approval of the application especially if the applicant and the approver is not in the workplace location. Based on these conditions a system is needed to assist in the regulation of leave and permit applications for employees and lecturers. The method used in developing this system is the Rapid Application Development (RAD) method. There are three phases in RAD namely planning, design workshops and implementation.
\end{abstract}

Keywords-information Systems; paid leave; permission; Webbased; Rapid Application Development;

Abstrak-Universitas Bina Darma adalah salah satu instansi pendidikan yang mempunyai kewajiban untuk memberikan hak cuti bagi karyawan dan dosennya. Untuk proses pelaksanaan, pengurusan, perhitungan, penggantian cuti akan menjadi tugas dari Direktorat Sumber Daya Manusia (DSDM). DSDM memiliki ketentuan mengenai aturan untuk memberikan cuti atau izin tidak masuk kerja. Staf Karyawan dan dosen yang akan mengajukan permohonan cuti harus menyampaikan pengajuan tersebut secara tertulis menggunakan formulir permohonan cuti. Penerapan cara manual ini memiliki beberapa kelemahan yaitu kurang efesien, butuh waktu yang lama karena belum terkomputerisasi. Selain itu kurang efektif dalam proses kerjanya, karena banyaknya pemakaian kertas sehingga sulit dalam pengontrolan persetujuan permohonan apalagi jika pemohon dan pemberi persetujuan tidak ada di lokasi tempat kerja. Berdasarkan kondisi tersebut diperlukan sebuah sistem yang dapat membantu aktifitas pengaturan permohonan cuti dan izin staf karyawan dan dosen. Metode yang di gunakan dalam pengembangan sistem ini adalah metode Rapid Application Development (RAD). Terdapat tiga fase dalam RAD yaitu planning, design workshop dan implementation.

Kata Kunci-sistem informasi; cuti; izin; berbasis web; Rapid Application Development;

\section{PENDAHULUAN}

Cuti adalah suatu kondisi dari seseorang untuk tidak masuk kerja karena cuti tahunan, bersalin, liburan atau alasan kepentingan lainnya yang di beri izin secara resmi dalam beberapa waktu tertentu. Izin atau absen kerja adalah suatu kondisi ketidak hadiran karyawan di sebabkan kondisi tertentu sesuai dengan peraturan dan ketetapan dari institusi, instansi atau perusahaan berdasarkan UU ketenaga kerjaan No. 13 Tahun 2013[1]. Pemberian cuti atau izin ini dimaksudkan agar kesegaran jasmani dan rohani seseorang agar tetap terjaga. Oleh karena ini seseorang yang telah bekerja dalam jangka waktu tertentu berhak mendapatkan cuti atau izin. Cuti atau izin adalah hak bagi setiap pegawai atau karyawan baik dari lingkungan pemerintah atau swasta. Seorang pekerja berhak atas cuti tahunan sekurang-kurangnya 12 hari kerja [2]. Pada umumnya instansi akan memberikan hak izin atau cuti untuk karyawannya yang bisa di gunakan adalah 12 hari atau lebih pertahun. Cuti sendiri terdiri dari cuti melahirkan, cuti sakit, cuti besar, cuti tahunan dan cuti karena alasan penting [3].

Dengan banyaknya jumlah karyawan yang di miliki oleh instansi-instansi yang ada di Indonesia, maka perlu adanya sistem informasi yang efektif guna mendukung dan meningkatkan efektivitas. Salah satu implementasi teknologi informasi yang sangat banyak diterapkan pada perusahaan yaitu sistem informasi kepegawaian, dimana salah satu nya adalah aplikasi pengajuan cuti [4]

Universitas Bina Darma adalah salah satu instansi pendidikan yang didirikan untuk turut serta secara aktif membantu pemerintah dalam melaksanakan program pembangunan nasional dalam rangka mewujudkan cita-cita nasional dan turut serta membantu pemerintah dalam upaya mencerdaskan kehidupan bangsa. [5] Universitas Bina Darma mempunyai kewajiban untuk memberikan hak cuti bagi staf karyawan dan dosennya, Untuk proses pelaksanaan, pengurusan, perhitungan, penggantian cuti menjadi tugas dari Direktorat Sumber Daya Manusia - Universitas Bina Darma (DSDM-UBD). DSDM-UBD memiliki ketentuan mengenai aturan untuk memberikan cuti atau izin tidak masuk kerja, biasanya karyawan dan dosen mengajukan permohonan terlebih dahulu. Karyawan dan dosen yang akan mengajukan permohonan cuti harus menyampaikan pengajuan tersebut secara tertulis menggunakan formulir permohonan cuti. Setelah permohonan tersebut disetujui oleh atasannya, staf karyawan 
dan dosen menyampaikan formulir permohonan cuti tersebut ke DSDM-UBD paling lambat 1 hari sebelum izin tersebut dilaksanakan kecuali untuk kepentingan sangat mendesak misalnya kabar duka, sakit dan lainnya. Sedangkan untuk izin tidak masuk kerja prosedurnya hampir sama kecuali untuk permasalahan apabila staf karyawan dan dosen datang terlambat atau tidak masuk kerja karena sesuatu hal yang sifatnya mendesak atau tidak dapat diduga sebelumnya, maka setelah kembali masuk kerja karyawan atau dosen diharuskan mengisi formulir permohonan izin, meminta tandatangan dari atasan lalu menyampaikannya ke DSDM-UBD. Setelah mendapatkan pengesahan atau cap persetujuan, barulah karyawan atau dosen dinyatakan mendapat cuti atau izin. Selanjutnya persetujuan pengajuan cuti atau izin di catat.

Penerapan cara pengajuan cuti dan izin ini memiliki beberapa kelemahan yaitu kurang efesien yaitu butuh waktu yang lama karena belum terintegrasi komputerisasi. Selain itu kurang efektif dalam proses kerjanya, karena banyaknya pemakain kertas sehingga sulit dalam pengontrolan persetujuan permohonan apalagi jika pemohon dan pemberi persetujuan tidak ada di lokasi tempat kerja. Berdasarkan kondisi tersebut diperlukan sebuah sistem yang dapat membantu aktifitas pengaturan permohonan cuti dan izin staf karyawan dan dosen di DSDM-UBD. Dengan adanya sistem ini di harapkan dapat memudahkan staf karyawan dan dosen dalam pengajuan cuti atau izin secara mendadak, bisa dapat dilakukakn pendelegasian pengganti untuk tugas lebih cepat, mempermudah dan mempercepat proses, serta dapat dikonfirmasi lebih cepat.

Metode yang di gunakan dalam pengembangan sistem ini adalah metode Rapid Application Development (RAD). Ada tiga fase dalam $R A D$ yang melibatkan penganalisis dan pengguna dalam tahap penilaian, perancangan, dan penerapan. Adapun ketiga fase tersebut adalah requirements planning (perencanaan syarat-syarat), RAD design workshop (workshop desain $R A D$ ), dan implementation (implementasi) [6].

\section{METODOLOGI PENELITIAN}

\section{A. Metode Pengembangan Perangkat Lunak}

Dalam melakukan penelitian untuk pengembangan sistem informasi pengajuan cuti dan izin berbasis web ini digunakan metode penelitian deskriptif. Penggunaan metode ini disebabkan yang akan dilakukan merupakan pengungkapan fenomena dan fakta yang dilakukan oleh peneliti [7].

Penelitian ini di laksanakan pada Direktorat Sumber Daya Manusia Universitas Bina Darma. Dalam penelitian ini dilakukakn pengujian sistem informasi pengajuan cuti dan izin berbasis web sebagai bahan uji coba implementasi. Metode yang di gunakan dalam pengembangan sistem informasi pengajuan cuti dan izin berbasis web ini adalah metode $R A D$. Metode Rapid Application Development (RAD) dipilih karena sesuai dengan kebutuhan pengembangan aplikasi yang cepat dan memiliki kebutuhan yang jelas [8]. Gambar 1 berikut ini adalah tahap-tahap pengembangan sistem informasi pengajuan cuti dan izin berbasis web.

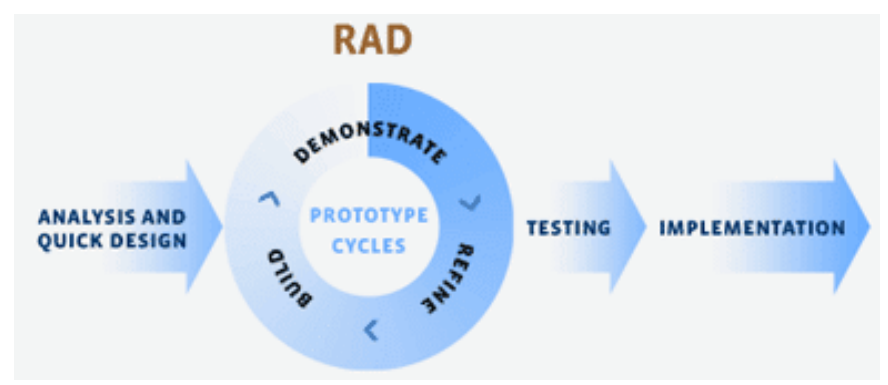

Gambar 1. Fase Metode $R A D$

Sumber : [9]

Untuk menghasilkan sistem informasi sesuai kebutuhan maka dalam proses pengembangan digunakan metode pengembangan yang sistematis, terstruktur dan berorientasi pada objek [10]. Fase pengembangan dari sistem informasi pengajuan cuti dan izin berbasis web dengan metode $R A D$ pada gambar 1 dapat dijelaskan sebagai berikut :

1) Requirements planning (perencanaan syarat-syarat). Dalam fase ini, pengguna dan penganalisis bertemu untuk mengidentifikasikan tujuan-tujuan aplikasi atau sistem serta untuk megidentifikasikan syarat-syarat informasi yang ditimbulkan dari tujuan-tujuan tersebut [6]. Kegiatan pada fase ini adalah menyelesaikan masalah dan syarat pada proses cuti dan izin yang masih manual yang ada sekarang. Seperti masalah kurang efesien, butuh waktu yang lama karena sistem belum terkomputerisasi, kurang efektif prosesnya karena masih banyak penggunaan kertas, sulit dalam pengontrolan dimana pemohon yaitu pimpinan atau staf dan pemberi persetujuan yaitu atasan dari pimpinan atau staf tidak ada di lokasi tempat kerja. Gambar 2 berikut memperlihatkan prose sistem yang akan diusulkan.

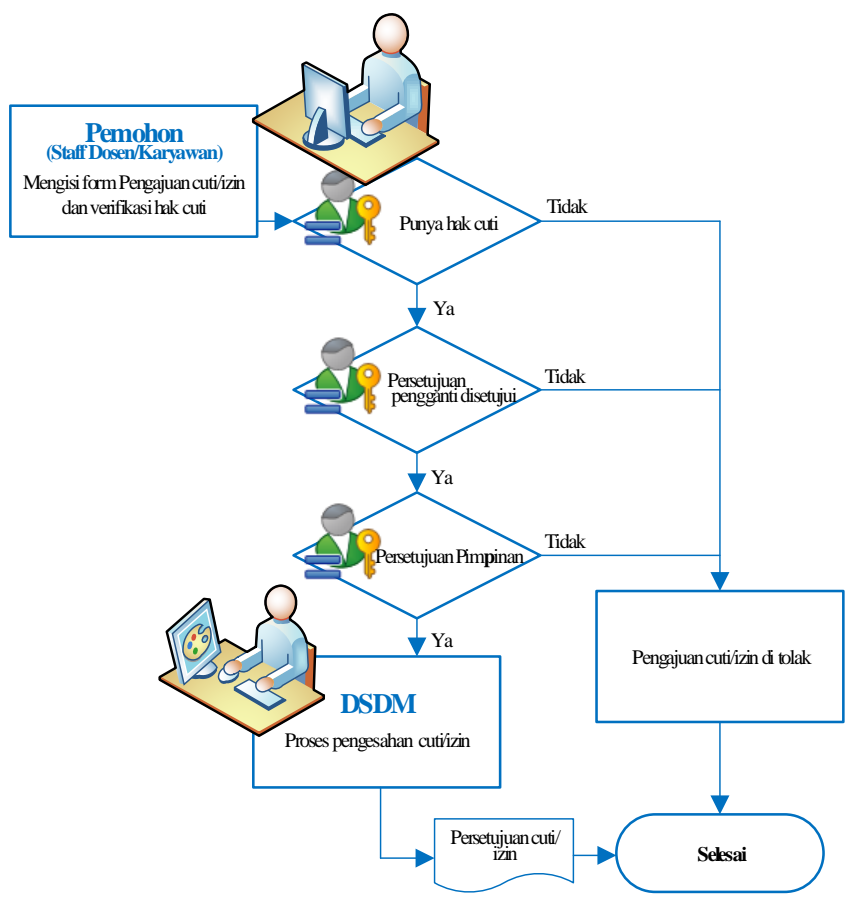

Gambar 2. Proses Sistem Pemberian Cuti dan Izin 
2). $R A D$ design workshop (workshop desain $R A D$ ), fase ini adalah fase untuk merancang dan memperbaiki yang bisa digambarkan sebagai workshop. Penganalisis dan pemrogram dapat bekerja membangun dan menunjukkan representasi visual desain dan pola kerja kepada pengguna. Selama workshop desain $R A D$, pengguna merespon prototipe yang ada dan penganalisis memperbaiki modulmodul yang dirancang berdasarkan respon pengguna [6]. Model data adalah kumpulan dari tabel berdimensi dua yang mempunyai keterhubungan, baris dan kolom untuk merepresentasikan suatu basis data. Ada banyak teknik yang digunakan di antara arsitek data untuk merancang model data, seperti entity relationship diagram (ERD) dan data matrix dan lain-lain. Dengan mengambil temuan dari model konseptual, struktur terperinci dari setiap entitas dirancang dalam model logis. Atribut entitas dan tipenya diidentifikasi pada level ini namun tipenya independen terhadap platform. Nama tabel dan nama kolom yang sebenarnya belum tentu cocok dengan nama entitas dan atribut dalam model logis [11]. Diagram class untuk menampilkan beberapa penggunaan dari kelas serta paket-paket yang ada dalam sistem perangkat lunak [12]. Adapun kelas-kelas yang ada pada sistem informasi pengajuan cuti dan izin berbasis web ini adalah auth_user, auth_user_user_ permissions, auth_group, auth_group_ permissions, profil_profil, izin_keperluanizin, cuti_jeniscuti, cuti_periodecuti, cuti_keperluancuti,izin_pengajuanizin, cuti_pengajuancuti, izin_pengajuan izindetil, izin_pimpinan, cuti_ pengajuancutidetil, cuti pimpinan dan cuti_pengganti. Gambar 3 berikut menunjukkan diagram class dari sistem informasi pengajuan cuti dan izin berbasis web.

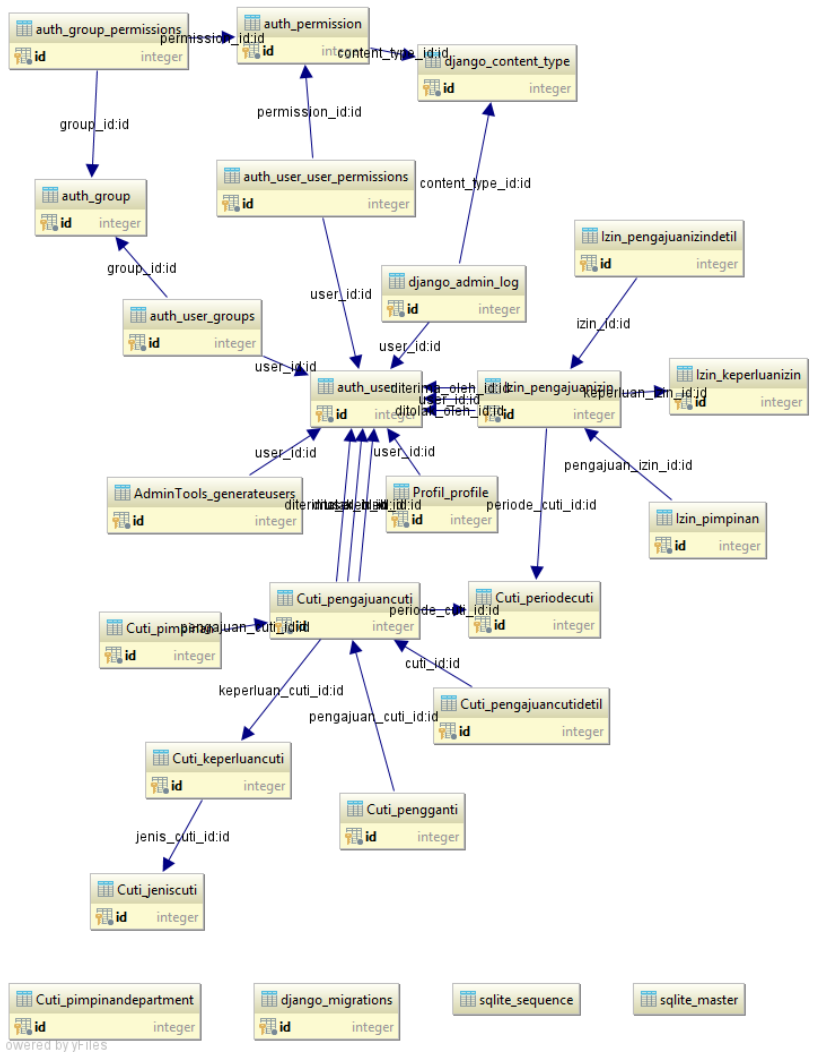

Gambar 3. Diagram class Sistem Cuti dan Izin
3) Implementation (implementasi), pada fase implementasi ini, penganalisis bekerja dengan para pengguna secara intens selama workshop dan merancang aspek-aspek bisnis dan nonteknis perusahaan. Segera setelah aspek-aspek ini disetujui dan sistem-sistem dibangun dan disaring, sistemsistem baru atau bagian dari sistem diujicoba dan kemudian diperkenalkan kepada organisasi [6].

\section{B. Teknik Pengumpulan Data}

Teknik pengumpulan data yang digunakan dalam melakukan penelitian ini adalah :

1) Observasi. Peneliti melihat dan mengamati semua permasalahan yang berhubungan dengan proses manual pengajuan izin dan cuti di DSDM-UBD. Dimana sistem manual memiliki beberapa kelemahan yaitu kurang efesien, kurang efektif dengan banyaknya pemakain kertas sehingga sulit dalam pengontrolan.

2) Wawancara. Peneliti mengumpulkan data secara langsung dengan Direktur DSDM-UBD selaku pengelola DSDM tentang kewajiban untuk memberikan hak cuti atau izin bagi staf karyawan dan dosen untuk proses pelaksanaan, pengurusan, perhitungan dan penggantian cuti atau izin.

3) Studi Pustaka. Dalam penelitian ini data di peroleh dan di kumpulkan dengan cara membaca dan mempelajari bukubuku, jurnal, majalah, macam-macam artikel dan referensi lainnya untuk mencari data-data dari sumber yang berhubungan dengan penelitian ini.

\section{HASIL DAN PEMBAHASAN}

Hasil dari penelitian yang telah dilakukan ini berupa sistem informasi pengajuan cuti dan izin berbasis web yang dapat digunakan oleh staf karyawan, dosen dan pimpinan di lingkungan Universitas Bina Darma dalam pengajuan cuti atau izin. Staf karyawan, dosen dan pimpinan mempunyai hak yang sama dalam proses permohonan cuti di sistem. Hak akses lain terdapat pada pengganti cuti dan atasan pemohon yang mempunyai hak untuk menggantikan tugas pada saat cuti pemohon dan memberi persetujuan untuk memberikan cuti.

Sistem ini di bangun dengan menggunakan bahasa pemrograman python versi 3.7.4. Python adalah bahasa pemrograman yang bersifat open source. Bahasa pemrograman ini dioptimalisasikan untuk software quality, developer productivity, program portability dan component integration [13]. Framework yang digunakan adalah django versi 2.0.4. Django merupakan framework back-end python untuk membangun sistem berbasis web [14]. Untuk sistem manajemen basis datanya menggunakan Microsoft $S Q L$ server. SQL digunakan untuk memanipulasi dan menarik data yang tersimpan pada IBM database management system yang disebut dengan System R. SQL ini dikembangkan setelah mempelajari model rasional dari manajemen basis data yang ditemukan oleh E. F Codd di awal tahun 1970 [15].

Dengan telah di implementasikannya sistem ini dapat mempermudah dan mempercepat proses pengajuan cuti dan izin staf karyawan dan dosen, dimana pengajuan bisa dilakukan secara mendadak kapan saja dan dimana saja selama masih 
terhubung ke jaringan internet. Sistem ini juga telah terintegrasi dengan sistem kepegawaian yang memuat data karyawan dan dosen serta data kehadiran atau presensi.

\section{A. Pengajuan Cuti}

Adapun hasil implementasi dari sistem pengajuan cuti ini dapat dijelaskan sebagai berikut. Pertama staf karyawan, dosen dan pimpinan sebagai pemohon cuti harus login ke sistem, lalu mengakses menu pengajuan cuti pada dashboard pegawai untuk membuat pengajuan cuti. Pada halaman dashboard untuk akses pegawai bisa dilihat pada gambar 4, terdapat 3 menu pilihan yaitu menu approval pengganti/persetujuan sebagai pengganti, pengajuan cuti dan pengajuan izin.

\section{Presensi Pegawai}

Site administration

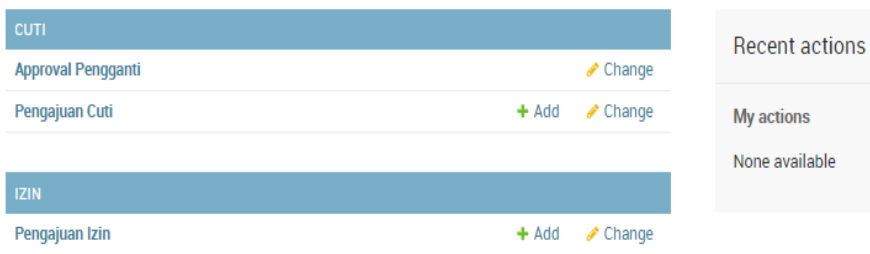

Gambar 4. Dashboard Pegawai

Untuk melakukan pengajuan cuti, kita perlu memilih tombol add pengajuan cuti, maka akan tampil sebuah form seperti pada gambar 5 dibawah ini. Kita akan diminta untuk mengisikan data-data yang tersedia, seperti kerperluan cuti, keterangan, orang yang akan mengganti ketika kita cuti, dan tanggal cuti yang kita inginkan. Jika sudah pasti dan yakin, maka kita bisa langsung memilih tombol ajukan, maka pengajuan cuti akan diteruskan ke pimpinan unit atau kepala bagian, jika belum yakin maka kita bisa memilih tombol save untuk menyimpan pengajuan cuti sebagai draft, sehingga masih bisa kita revisi dan ketika sudah yakin tidak ada revisi maka baru kita tekan tombol ajukan.

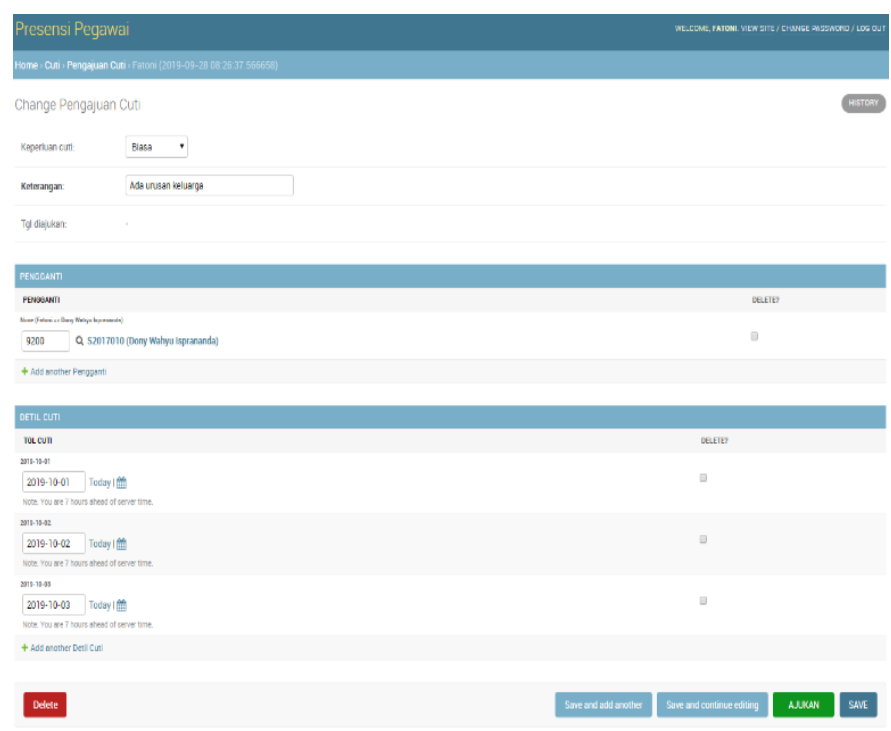

Gambar 5. Form Pengajuan Cuti
Ketika kita sudah memilih tombol "Ajukan", maka pengajuan Cuti yang kita ajukan tidak dapat lagi kita edit, kita hanya dapat melihat proses dari pengajuan cuti kita tersebut, apakah sudah di setujui oleh pengganti atau ditolak, kapan waktu pengajuan diterima oleh pengganti dan kapan waktu pengajuan ditolak oleh pengganti. Kita juga bisa melihat apakah pengajuan sudah disetujui oleh pimpinan unit atau kepala bagian, atau ditolak oleh pimpinan unit atau kepala bagian dan kapan waktu pengajuan disetujui oleh pimpinan unit atau kepala bagian dan kapan waktu pengajuan ditolak oleh pimpinan unit atau kepala bagian.

Selanjutnya pada bagian pengganti pada bagian "Approval Pengganti", ketika kita membuka pengajuan cuti yang membutuhkan persetujuan dari kita, maka ketika kita membuka data pengajuan tersebut maka pada bagian bawah akan terdapat 2 tombol yaitu tombol "TOLAK" atau "TERIMA", jika kita memilih tombol "TOLAK" maka pengajuan cuti tersebut akan stop sampai disini dan pemohon cuti harus membuat pengajuan baru dan memilih pengganti cuti yang lain dan jika kita memilih tombol "TERIMA" maka pengajuan cuti tersebut akan diteruskan ke persetujuan pimpinan unit atau kepala bagian. Untuk pimpinan unit apakah menyetujui pengajuan cuti tersebut atau tidak.

Pada bagian "Approval Pengganti" pengajuan yang telah disetujui atau ditolak oleh pimpinan tidak dapat diubah lagi, karena tombol "TERIMA" dan "TOLAK" sudah tidak ada lagi karena pengajuan tersebut telah kita setujui atau kita tolak dan kita bisa melihat kapan kita menyetujui atau menolak pengajuan tersebut.

Pada bagian pimpinan pada gambar 6, akan terdapat menu "Approval Pimpinan" yang berisikan data pengajuan cuti yang berisikan data pengajuan cuti yang membutuhkan persetujuan dari pimpinan, untuk memberikan persetujuan, pimpinan perlu membuka data pengajuan cuti tersebut, lalu akan tampil data detail pengajuan cuti dan pada bagian bawah akan terdapat tombol "TOLAK" dan tombol "TERIMA", ketika pimpinan memilih tombol "TOLAK" maka pengajuan cuti tersebut akan stop sampai disini namun jika pimpinan memilih tombol "TERIMA", maka pengajuan cuti akan diteruskan ke DSDM.

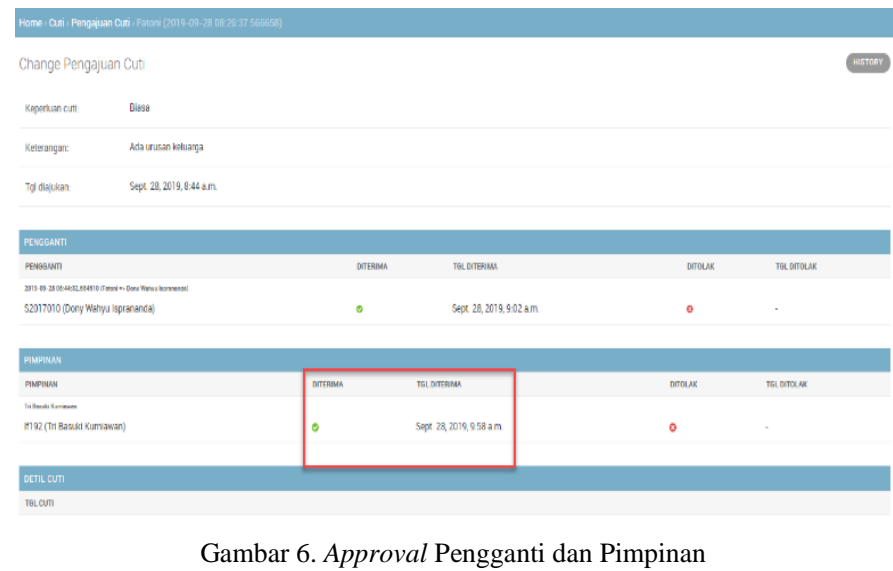

Perubahan status pengajuan cuti ketika sudah mendapatkan persetujuan dari pimpinan maka status akan berubah menjadi "PERSETUJUAN DSDM", yang berarti sedang menunggu persetujuan dari DSDM. 
Presensi Pegawai

Site administration

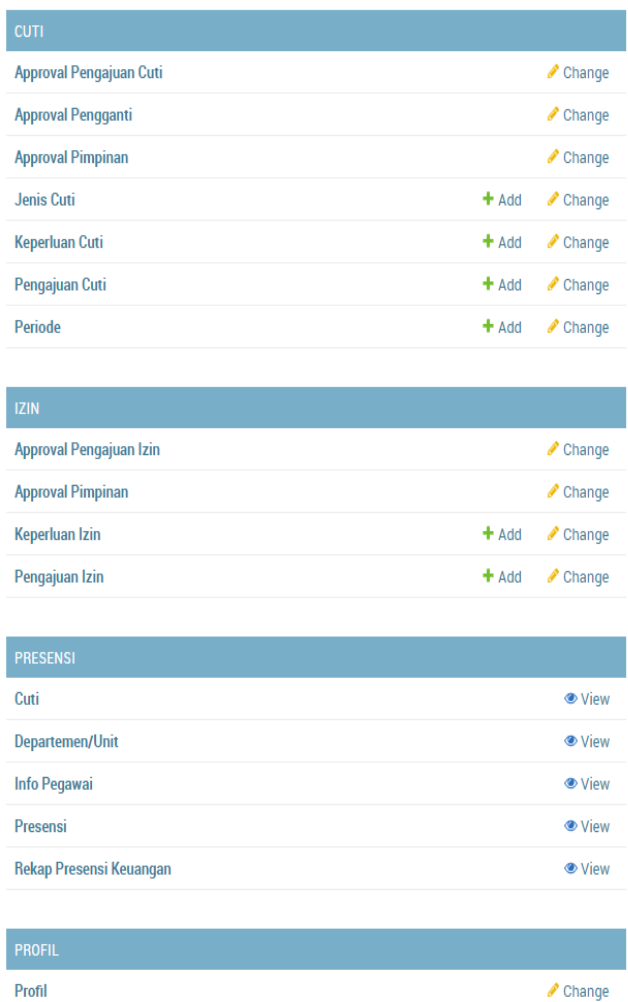

Recent actions

My actions

Melahirkan

Keperluan curti

Pegawai 001 (2019-07-01 08:44:46.895986)

Pegawai 001 (2019-07-01 08:44:46.895986) Pegawai 001 (2019-07-01 08:44:46.895986)

Biasa

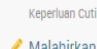

Malahirk Keperluan
Dinas
Kepertuan Izin Belajar Izin Belaja
Kepertunan Sakit Kep Pegawai 001 (2019-07-01 08:44:46.895986)

Gambar 7. Dashboard DSDM

Pada Dashboard DSDM gambar 7 diatas terdapat beberapa menu dan module. Pada menu cuti ada module approval pengajuan, approval pengganti, jenis cuti, keperluan cuti, pengajuan cuti dan periode. Pada menu izin ada module approval pengajuan izin, approval pimpinan, keperluan izin dan pengajuan izin. Pada menu presensi ada module cuti, departemen/unit, info pegawai, presensi dan rekap presensi keuangan. Terakhir menu profil.

DSDM dapat melihat data pengajuan cuti yang belum mendapatkan persetujuan atau penolakan, DSDM juga dapat mencari data pengajuan, memfilter data pengajuan. Ketika melihat detail dari data pengajuan cuti maka akan tampil detail dari pengajuan cuti, dan pada bagian bawah terdapat 2 tombol, yaitu: tombol "TOLAK" dan tombol "TERIMA". Ketika DSDM memberikan penolakan dengan memilih tombol "TOLAK", maka pengajuan cuti tersebut tidak akan masuk ke data absensi, tetapi ketika DSDM memberikan persetujuan dengan memilih tombol "TERIMA", maka pengajuan cuti tersebut akan masuk ke data absensi dan ketika terjadi penarikan data absensi, maka pada tanggal-tanggal cuti tersebut akan dianggap cuti dan bukan dianggap tidak hadir. Jika dilihat dari detail pengajuan maka akan tampil kapan pengajuan cuti ini ditolak dan siapa yang menolaknya seperti pada gambar 8 berikut.

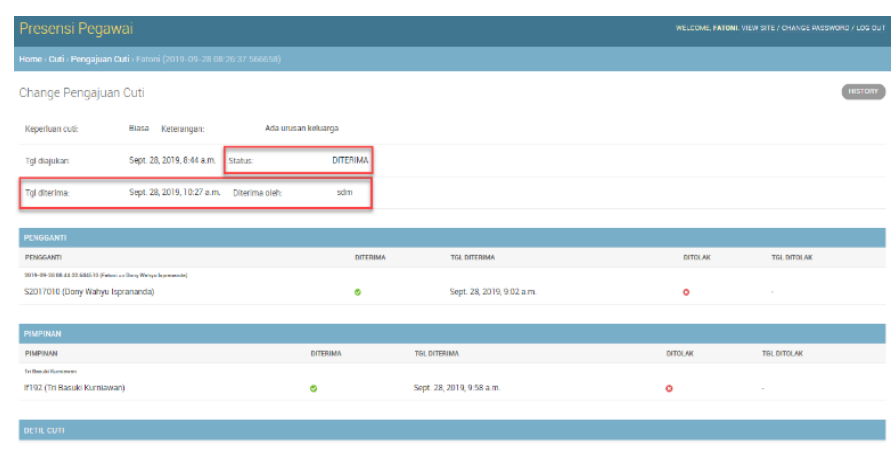

Gambar 8. Status Detail Pengajuan

\section{B. Pengajuan Izin}

Untuk melakukan pengajuan izin, kita perlu memilih tombol add pengajuan izin, maka akan tampil sebuah form pengajuan izin seperti pada gambar 9, Selanjutnya kita akan diminta untuk mengisikan data-data yang tersedia, seperti kerperluan izin, keterangan, orang yang akan mengganti kita ketika kita izin, dan tanggal-tanggal izin yang kita inginkan. Jika sudah pasti dan yakin dengan data-data yang diisikan, maka kita bisa langsung memilih tombol "AJUKAN", maka pengajuan izin akan diteruskan ke pimpinan unit atau bagian, jika belum yakin maka kita bisa memilih tombol "SAVE" untuk menyimpan pengajuan izin sebagai draft sehingga data-data yang telah kita isikan masih bisa kita revisi dan ketika sudah yakin dengan data tersebut maka baru kita ajukan.

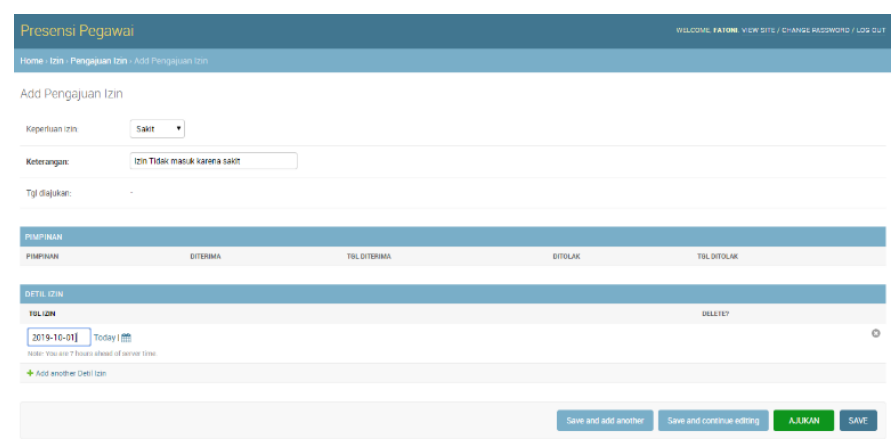

Gambar 9. Form Pengajuan Izin

Untuk proses keseluruhan pengajuan izin ini tata caranya hampir sama dengan proses permohonan cuti. Pada bagian "Approval Pimpinan" akan tampil data dengan status "PERSETUJUAN PIMPINAN", pimpinan juga dapat mencari data pengajuan yang telah di setujui atau di tolak dan dapat juga memfilter data pengajuan yang belum mendapatkan persetujuan atau penolakan seperti pada gambar 10 dibawah.

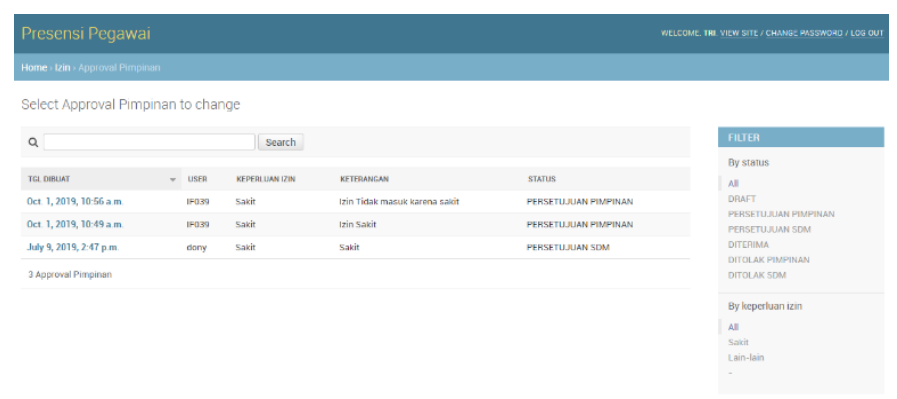

Gambar 10. Form Izin Approval Pimpinan 
Ketika data pengajuan izin tersebut dibuka maka akan tampil data detail mengenai pengajuan izin tersebut. Untuk mengenai siapa penggantinya dan kapan di setujui dan pada bagian akhir terdapat 2 tombol yaitu tombol "TOLAK" dan tombol "TERIMA" yang menandakan bahwa data pengajuan ini belum mendapatkan persetujuan dari pimpinan. Ketika pimpinan memilih tombol "TOLAK" maka pengajuan izin ini stop sampai disini dan jika pengajuan izin tersebut diterima maka pengajuan izin tersebut akan diteruskan ke DSDM.

Data detail pengajuan izin ketika sudah mendapatkan persetujuan atau penolakan dari pimpinan, maka nilai dari field diterima atau ditolak dari bagian pimpinan maka akan berubah menjadi tanda centang dan informasi mengenai kapan pengajuan tersebut disetujui oleh pimpinan dan kapan pengajuan tersebut di tolak oleh pimpinan akan di tampilkan.

DSDM dapat melihat data pengajuan izin yang belum mendapatkan persetujuan atau penolakan. DSDM juga dapat mencari data pengajuan dan memfilter data pengajuan. Ketika melihat detail dari data pengajuan izin maka akan tampil detail dari pengajuan izin dan pada bagian bawah terdapat 2 tombol, yaitu tombol "TOLAK" dan tombol "TERIMA". Ketika DSDM memberikan penolakan dengan memilih tombol "TOLAK" maka pengajuan izin tersebut tidak akan masuk ke data absensi tetapi ketika DSDM memberikan persetujuan dengan memilih tombol "TERIMA", maka pengajuan izin tersebut akan masuk ke data absensi dan ketika terjadi penarikan data absensi maka pada tanggal-tanggal izin tersebut akan dianggap izin dan bukan dianggap tidak hadir.

Untuk memastikan sistem ini berjalan dengan baik maka dilakukan pengujian untuk setiap proses dari sistem informasi pengajuan cuti dan izin berbasis web ini. Pengujian merupakan proses verifikasi dan validasi apakah sistem informasi yang dihasilkan telah berfungsi dengan baik atau tidak. Untuk itu proses pengujian ini dilakukan dengan teknik pengujian black box [10]. Hasil pengujian menggunakan teknik black box seperti yang ditampilkan pada table I sampai dengan table $\mathrm{V}$ menunjukkan bahwa semua komponen sistem informasi pengajuan cuti dan izin berbasis web dikategorikan diterima yaitu mampu berfungsi dengan baik. Hasil pengujian untuk masing-masing proses sistem informasi dapat dilihat pada table I sampai dengan table $\mathrm{V}$ berikut.

TABLE I. HASIL PENGUJIAN LOGIN

\begin{tabular}{|l|l|}
\hline Kasus dan Hasil Ujicoba (Data Benar) \\
\hline Data masukan & Username : IF039 Password : benar \\
\hline $\begin{array}{l}\text { Yang } \\
\text { diharapkan }\end{array}$ & $\begin{array}{l}\text { Setelah mengisi } \text { username dan password yang benar } \\
\text { kemudian klik button login maka akan menampilkan } \\
\text { halaman dashboard pegawai }\end{array}$ \\
\hline Pengamatan & $\begin{array}{l}\text { Username dan password yang dimasukan dapat } \\
\text { diterima dan button login berfungsi dengan baik dan } \\
\text { dapat menampilkan halaman dashboard pegawai }\end{array}$ \\
\hline Kesimpulan & {$[\checkmark$ ] Diterima [ ] Ditolak } \\
\hline Kasus dan Hasil Ujicoba (Data Salah) \\
\hline Data masukan & Username : IF039 Password : salah \\
\hline $\begin{array}{l}\text { Yang } \\
\text { diharapkan }\end{array}$ & $\begin{array}{l}\text { Setelah mengisi } \text { username dan password kemudian } \\
\text { menekan tombol button login, kemudian halaman } \\
\text { login ditampilkan kembali }\end{array}$ \\
\hline Pengamatan & $\begin{array}{l}\text { Setelah memasukan } \text { username dan password yang } \\
\text { tidak sesuai maka menampilkan halaman login. }\end{array}$ \\
\hline Kesimpulan & {$[\checkmark$ ] Diterima [ ] Ditolak } \\
\hline
\end{tabular}

TABle II. Pengujian Data Pengajuan Cuti

\begin{tabular}{|c|c|}
\hline \multicolumn{2}{|c|}{ Kasus dan Hasil Ujicoba } \\
\hline \multicolumn{2}{|c|}{ Input data Pengajuan Cuti } \\
\hline Data masukan & $\begin{array}{l}\text { Memasukan data pengajuan cuti sesuai dengan field } \\
\text { yang disediakan (keperluan cuti, keterangan cuti, } \\
\text { tanggal diajukan, nama pengganti dan tanggal- } \\
\text { tanggal cuti yang diajukan) }\end{array}$ \\
\hline $\begin{array}{l}\text { Yang } \\
\text { diharapkan }\end{array}$ & $\begin{array}{l}\text { Proses masukkan data. Klik button save dan button } \\
\text { ajukan, data disimpan ke database dan menampilkan } \\
\text { daftar proses pengajuan cuti status "menunggu } \\
\text { persetujuan pengganti" }\end{array}$ \\
\hline Pengamatan & $\begin{array}{l}\text { Data pengajuan cuti berhasil dimasukan ke database } \\
\text { dan menampilkan daftar proses pengajuan cuti } \\
\text { sesuai dengan yang diharapkan }\end{array}$ \\
\hline Kesimpulan & {$[\checkmark]$ Diterima [ ] Ditolak } \\
\hline \multicolumn{2}{|c|}{ Edit data Pengajuan Cuti Masih Draft } \\
\hline Data masukan & $\begin{array}{l}\text { Memilih data pengajuan cuti yang akan diubah dari } \\
\text { daftar pengajuan cuti, (belum klik button ajukan atau } \\
\text { status } d \text { raft) }\end{array}$ \\
\hline $\begin{array}{l}\text { Yang } \\
\text { diharapkan }\end{array}$ & $\begin{array}{l}\text { Dapat menampilkan draft data pengajuan cuti, dapat } \\
\text { merubah data pengajuan cuti, kemudian proses } \\
\text { disimpan, menampilkan proses edit sukses } \\
\text { dilakukan kembali ke daftar proses pengajuan cuti }\end{array}$ \\
\hline Pengamatan & $\begin{array}{l}\text { Data pengajuan cuti dapat di edit dan kembali ke } \\
\text { daftar proses pengajuan cuti }\end{array}$ \\
\hline Kesimpulan & {$[\checkmark]$ Diterima [ ] Ditolak } \\
\hline \multicolumn{2}{|c|}{ Delete data Pengajuan Cuti Masih Draft } \\
\hline Data masukan & $\begin{array}{l}\text { Memilih data pengajuan cuti pada daftar proses } \\
\text { pengajuan cuti status } d r a f t\end{array}$ \\
\hline $\begin{array}{l}\text { Yang } \\
\text { diharapkan }\end{array}$ & $\begin{array}{l}\text { menampilkan pesan proses penghapusan data } \\
\text { berhasil, dan kembali ke daftar data proses } \\
\text { pengajuan cuti }\end{array}$ \\
\hline Pengamatan & $\begin{array}{l}\text { Menampilkan pesan penghapusan data berhasil dan } \\
\text { kembali ke daftar data proses pengajuan cuti }\end{array}$ \\
\hline Kesimpulan & {$[\checkmark]$ Diterima [ ] Ditolak } \\
\hline
\end{tabular}

\section{TABLE III. PENGUJian DATA PERSETUJuAN} PENGGANTI

\begin{tabular}{|c|c|}
\hline \multicolumn{2}{|c|}{ Kasus dan Hasil Ujicoba “TERIMA” } \\
\hline Data masukan & $\begin{array}{l}\text { Menerima atau menolak persetujuan sebagai } \\
\text { pengganti dengan klik button terima }\end{array}$ \\
\hline $\begin{array}{l}\text { Yang } \\
\text { diharapkan }\end{array}$ & $\begin{array}{l}\text { Proses masukkan data. Klik button terima maka } \\
\text { akan menampilkan status tercentang dan pada } \\
\text { tanggal diterima akan menampilkan data kapan } \\
\text { pengajuan cuti tersebut disetujui oleh pengganti. }\end{array}$ \\
\hline Pengamatan & $\begin{array}{l}\text { Pada bagian "Approval Pengganti", pengajuan yang } \\
\text { telah disetujui, tidak dapat diubah lagi, karena } \\
\text { tombol "TERIMA" sudah tidak ada lagi karena } \\
\text { pengajuan tersebut telah di setujui, maka pengajuan } \\
\text { cuti tersebut akan diteruskan untuk meminta } \\
\text { persetujuan ke pimpinan. Pada bagian "Approval } \\
\text { Pimpinan" akan tampil data dengan status } \\
\text { "PERSETUJUAN PIMPINAN", }\end{array}$ \\
\hline Kesimpulan & {$[\checkmark]$ Diterima [ ] Ditolak } \\
\hline \multicolumn{2}{|c|}{ Kasus dan Hasil Ujicoba "TOLAK" } \\
\hline Data masukan & $\begin{array}{l}\text { Menerima atau menolak persetujuan sebagai } \\
\text { pengganti dengan klik button tolak }\end{array}$ \\
\hline $\begin{array}{l}\text { Yang } \\
\text { diharapkan }\end{array}$ & $\begin{array}{l}\text { Proses masukkan data. Klik button tolak maka akan } \\
\text { menampilkan status tercentang dan pada tanggal } \\
\text { ditolak akan menampilkan data kapan pengajuan } \\
\text { cuti tersebut ditolak oleh pengganti. }\end{array}$ \\
\hline Pengamatan & $\begin{array}{l}\text { Pada bagian "Approval Pengganti", pengajuan yang } \\
\text { telah ditolak, tidak dapat diubah lagi, karena tombol } \\
\text { "TOLAK" sudah tidak ada lagi karena pengajuan } \\
\text { tersebut telah di tolak. Proses pengajuan cuti } \\
\text { tersebut akan berhenti sampai disini, dan pemohon } \\
\text { cuti harus membuat pengajuan baru dan memilih } \\
\text { pengganti cuti yang lain }\end{array}$ \\
\hline Kesimpulan & {$[\checkmark]$ Diterima [ ] Ditolak } \\
\hline
\end{tabular}


TABle IV. Pengujian Data Persetujuan Pimpinan

\begin{tabular}{|l|l|}
\hline Kasus dan Hasil Ujicoba "TERIMA" \\
\hline Data masukan & $\begin{array}{l}\text { Menerima atau menolak persetujuan sebagai } \\
\text { pimpinan dengan klik button terima }\end{array}$ \\
\hline $\begin{array}{l}\text { Yang } \\
\text { diharapkan }\end{array}$ & $\begin{array}{l}\text { Proses masukkan data. Klik button terima maka } \\
\text { akan menampilkan status tercentang dan pada } \\
\text { tanggal diterima akan menampilkan data kapan } \\
\text { pengajuan cuti tersebut disetujui oleh pimpinan. }\end{array}$ \\
\hline Pengamatan & $\begin{array}{l}\text { Perubahan status pengajuan cuti ketika sudah } \\
\text { mendapatkan persetujuan dari pimpinan, status } \\
\text { berubah menjadi "PERSETUJUAN SDM", yang } \\
\text { berarti sedang menunggu persetujuan dari DSDM. }\end{array}$ \\
\hline Kesimpulan & {$[\checkmark$ ] Diterima [ ] Ditolak } \\
\hline Kasus dan Hasil Ujicoba "TOLAK" \\
\hline Data masukan & $\begin{array}{l}\text { Menerima atau menolak persetujuan sebagai } \\
\text { pimpinan dengan klik button tolak }\end{array}$ \\
\hline $\begin{array}{l}\text { Yang } \\
\text { diharapkan }\end{array}$ & $\begin{array}{l}\text { Proses masukkan data. Klik button tolak maka akan } \\
\text { menampilkan status tercentang dan pada tanggal } \\
\text { ditolak akan menampilkan data kapan pengajuan } \\
\text { cuti tersebut ditolak oleh pimpinan. }\end{array}$ \\
\hline Kesimpulan & $\begin{array}{l}\text { Ketika pimpinan klik button "TOLAK", maka } \\
\text { pengajuan cuti ini berhenti sampai disini dan tidak } \\
\text { diteruskan ke DSDM. Pemohon cuti harus membuat } \\
\text { pengajuan baru. }\end{array}$ \\
\hline [ $\checkmark$ Diterima [ ] Ditolak \\
\hline
\end{tabular}

TABLE V. Pengujian Data PersetujuAn DSDM

\begin{tabular}{|l|l|}
\hline Kasus dan Hasil Ujicoba "TERIMA" \\
\hline Data masukan & $\begin{array}{l}\text { Menerima atau menolak persetujuan sebagai } \\
\text { Direktur DSDM dengan klik button terima }\end{array}$ \\
\hline $\begin{array}{l}\text { Yang } \\
\text { diharapkan }\end{array}$ & $\begin{array}{l}\text { Proses tampil detail pengajuan cuti. Klik button } \\
\text { terima maka akan menampilkan status diterima }\end{array}$ \\
\hline Pengamatan & $\begin{array}{l}\text { Ketika SDM memberikan persetujuan dengan } \\
\text { menekan tombol "TERIMA", maka pengajuan cuti } \\
\text { tersebut akan masuk ke data presensi dan ketika } \\
\text { terjadi penarikan data presensi, maka pada tanggal- } \\
\text { tanggal cuti tersebut akan dianggap sebagai cuti. }\end{array}$ \\
\hline Kesimpulan & {$[\checkmark$ ] Diterima [ ] Ditolak } \\
\hline Kasus dan Hasil Ujicoba "TOLAK" \\
\hline Data masukan & $\begin{array}{l}\text { Menerima atau menolak persetujuan sebagai } \\
\text { Direktur DSDM dengan klik button tolak }\end{array}$ \\
\hline $\begin{array}{l}\text { Yang } \\
\text { diharapkan }\end{array}$ & $\begin{array}{l}\text { Proses tampil detail pengajuan cuti. Klik button } \\
\text { tolak maka akan menampilkan status ditolak }\end{array}$ \\
\hline Pengamatan & $\begin{array}{l}\text { Ketika SDM memberikan penolakan dengan } \\
\text { menekan tombol "TOLAK", maka pengajuan cuti } \\
\text { tersebut tidak akan masuk ke data presensi. }\end{array}$ \\
\hline Kesimpulan & $\sqrt{ }$ ] Diterima [ ] Ditolak \\
\hline
\end{tabular}

\section{PENUTUP}

Sistem informasi pengajuan cuti dan izin berbasis web ini mempermudah pemohon dalam hal ini staf karyawan, dosen dan pimpinan dalam mengajukan permohonan cuti atau izin kerja. Pemohon hanya perlu mengisi form pengajuan pada sistem tanpa harus mengisikan data diri karena setiap data pemohon sudah terintegrasi ke data pegawai. Pimpinan yang menjadi tujuan disetujuinya pengajuan cuti dan izin tersebut akan mendapatkan pemberitahuan dari proses pengajuan pada sistem. Fitur pendukung lainnya yang dapat mempercepat proses pengajuan adalah pemohon dan atasan bisa melihat jatah hari cuti yang masih tersedia. DSDM bisa mengetahui data cuti dan izin yang sudah disetujui pimpinan bagian atau unit dan disetiap akhir bulan DSDM dapat membuat berbagai macam laporan dengan cepat karena informasi dan data sudah terintegrasi. Jadi dengan tersedianya sistem ini manajemen cuti dan izin lebih mudah, akses lebih fleksibel, data lebih aman dan rapi karena tersimpan didatabase server, delegasi tugas yang ditinggalkan lebih cepat dan mudah serta bisa menampilkan data sisa hari cuti secara real-time serta terintegrasi dengan mesin absensi.

\section{UCAPAN TERIMA KASIH}

Terima kasih Penulis ucapkan kepada semua pihak atas selesai dan terlaksananya penelitian ini yaitu kepada Universtias Bina Darma khususnya Direktorat Sumber Daya Manusia - Universitas Bina Darma (DSDM-UBD) sebagai tempat objek penelitian yang telah memberikan data berupa akses informasi. Terima kasih juga kami sampaikan kepada redaksi Jurnal Sisfokom yang telah bersedia meluangkan waktu untuk melakukan review dan menerbitkan artikel ini.

\section{DAFTAR PUSTAKA}

[1] B. Kesowo, "Undang-Undang Republik Indonesia Nomor 13 Tahun 2003," no. 1. 2003.

[2] M. S. P. Imam Solikin, "APLIKASI CUTI DOSEN BERBASIS ANDROID PADA STEBIS ISLAM DARUSSALAM,” Kumpul. J. Ilmu Komput., vol. 6, pp. 173-183, 2019.

[3] F. Adikara, "Pengembangan Fungsi Pengajuan Cuti Karyawan pada Sistem Absensi Mobile," sisfo, vol. 6, no. 1, pp. 75-86, 2016.

[4] S. Susilowati and R. Widiana, "Penerapan Website Sistem Pengajuan Cuti Pegawai Pada Kantor Kecamatan Ciawi Bogor," J-SAKTI (Jurnal Sains Komput. dan Inform., vol. 3, no. 2, pp. 327-336, 2019, doi: 10.30645/j-sakti.v3i2.151.

[5] U. B. Darma, "Sejarah," 2018. [Online]. Available: https://www.binadarma.ac.id/sejarah/.

[6] J. E. K. Kenneth E. Kendall, Analisis dan Perancangan Sistem, 1-5/E ed. Jakarta: Indeks, 2010.

[7] M. Rahardjo, Studi Kasus Dalam Penelitian Kualitatif: Konsep Dan Prosedurnya. 2017.

[8] R. A. Hamzah, Ristu Saptono, "Development of Software Size Estimation Application using Function Point Analysis (FPA) Approach with Rapid Application Development (RAD)," ITSMART J. Teknol. dan Inf., vol. 5, pp. 96-103, 2016, doi: https://doi.org/10.20961/itsmart.v5i2.1988.

[9] Nurhidayat, "8 Macam Model Metode SDLC (System Development Life Cycle)," $2018 . \quad$ [Online]. Available: https://www.nurhidayat.id/2018/09/macam-model-metode-sdlc.html.

[10] F. Fatoni and D. Irawan, "Implementasi Metode Extreme Programming dalam Pengembangan Sistem Informasi Izin Produk Makanan," J. Sisfokom (Sistem Inf. dan Komputer), vol. 8, no. 2, p. 159, 2019, doi: 10.32736/sisfokom.v8i2.679.

[11] J. C. Rayan, "Data Modelling using ERD with Crow Foot Notation," $2015 . \quad$ [Online]. Available: https://www.codeproject.com/articles/878359/data-modelling-usingerd-with-crow-foot-notation.

[12] I. D. A. E. Y. Sandy Kosasi, "PENERAPAN RAPID APPLICATION DEVELOPMENT PADA SISTEM PENJUALAN SEPEDA ONLINE," SIMETRIS, vol. 6, pp. 27-36, 2015, doi: 10.24176/simet.v6i1.234.

[13] A. F. Harismawan, A. P. Kharisma, and T. Afirianto, "Analisis Perbandingan Performa Web Service Menggunakan Bahasa Pemrograman Python, PHP, dan Perl pada Client Berbasis Android," J. Pengemb. Teknol. Inf. dan Ilmu Komput. Univ. Brawijaya, vol. 2, no. 1, pp. 237-245, 2018.

[14] P. W. Cahyo and A. I. Wicaksono, "Django Framework and PythonGammu as Middleware SMS Broadcast," Compiler, vol. 8, no. 1, pp. 2734, 2019, doi: 10.28989/compiler.v8i1.430.

[15] W. N. Suliyanti, "Studi Literatur Basis Data SQL dan NoSQL," KILAT, vol. 8, no. 1, pp. 48-51, 2019, doi: 10.33322/kilat.v8i1.460. 